\title{
La voz inconformista de Patrick Kavanagh
}

\author{
Maximiliano Brina \\ Magíster, Universidad de Buenos Aires, Argentina
}

Copyright (c) 2015 by Maximiliano Brina. This text may be archived and redistributed both in electronic form and in hard copy, provided that the author and journal are properly cited and no fee is charged for access.

Resumen. Entre los poetas irlandeses de la primera mitad del siglo XX, Patrick Kavanagh, poeta rural y autodidacta, destacó por su visión crítica, entre el rechazo y la desconfianza, de programas nacionalistas literarios y políticos. Frente a la representación cuasi mítica del campesinado construida por el Irish Literary Revival, luego recuperada y utilizada por los republicanos como la síntesis de lo irlandés, una suerte de "ser nacional" construido por elites urbanas, Kavanagh presenta una mirada única, que oscila entre la desolación y la sátira. La propuesta de este artículo es examinar, a partir de "The Great Hunger" (1942) y poemas previos, la forma en que Kavanagh desmonta la construcción de esa visión urbana del campesinado irlandés.

Palabras clave. Patrick Kavanagh, poesía, "The Great Hunger", nacionalismo, religión, representación, tradición, campesinado, pastoril.

\begin{abstract}
Patrick Kavanagh, rural and self-taught poet, stands out among the Irish poets of the early twentieth century for his critical consideration of literary and political nationalist programs. Facing the quasi mythical representation of the peasantry built by the Irish Literary Revival, which was later used by the Republicans as a synthesis of Irishness, Kavanagh offers a unique opinion, ranging between despair and satire. The purpose of this article is to examine, from "The Great Hunger" (1942) and previous poems, the way Kavanagh disassembles this urban vision of the Irish peasantry.
\end{abstract}

Key Words. Patrick Kavanagh, Poetry, "The Great Hunger”, Nationalism, Religion, Representation, Tradition, Peasantry, Pastoral.

altivo, gerifalte Poeta, ayúdame: a luz más cierta, súbeme: la patria no es la tierra, el hombre no es el árbol: ayúdame a vivir sin suelo y sin raíces: móvil, móvil: sin otro alimento y sustancia que tu rica palabra: palabra sin historia, orden verbal autónomo, engañoso delirio: poema: imaginación y razón en ti se aúnan a tu propio servicio: palabra liberada de secular servidumbre

Juan Goytisolo - Reivindicación del Conde Don Julián

Nacido lejos de Dublín, en el condado de Monaghan donde residió hasta fines de la década de 1930, Patrick Kavanagh tuvo una formación literaria autodidacta paralela al trabajo rural. Su visión crítica del Irish Literary
Revival y la entronización de un campesinado cuasi-mítico construido desde la ciudad ("I'm the only man who has written in our time about rural Ireland from the inside", citado en Campbell 2003: 42) así como la posición crítica, 
entre la desconfianza y el rechazo, frente a proyectos nacionales políticos y literarios a los que opuso el parochialism y la sátira en poemas como "The Wake of the Books (A Mummery)" o "Who killed James Joyce?" hacen de este poeta un punto de quiebre dentro del panorama literario irlandés de la primera mitad del siglo XX. Mi propuesta de trabajo es concentra en un corpus conformado por poemas producidos entre 1929 y 1949, con particular interés en "The Great Hunger", de 1942.

La particularidad de Kavanagh impone la formalidad de una breve contextualización, un marco desde el cual abordaré al poeta para describir desde dónde construye su voz (y contra quién). En primer lugar, el Irish Literary Revival o simplemente Revival, movimiento que entre las últimas décadas del siglo XIX y las primeras del XX recuperó el interés por la herencia y tradición gaélica. Se destaca la figura de Yeats tanto por el inédito rigor que impuso a la poesía como por sus exploraciones en torno a la identidad Irlandesa (y, por extensión, las de sus poetas) que se nutrieron de elementos legendarios y tradicionales recuperados por el citado movimiento. Tras la firma del Tratado anglo-irlandés en 1922 se acentuó la veta política del Revival generando una amalgama, "neo-Revivalist poets were not merely influenced by official ideology; the official ideology was a form of poetry, an aestheticised mode of the anti-British struggle based on an inversion of colonial discourses" (Campbell 2003: 23). Este "revamped ruralist ideal, suitably Catholicised and purged of its English and continental taints, played a large role in the process of state formation" (ibid: 24) y en el proceso tomó distancia de Yeats ya que una sutil diferencia con el Revival original fue imponer una masculinidad gaélica a la sumisa feminidad celta. Esta tensión se advierte en la manera en que Kavanagh articuló su experiencia en contraste con la imagen idealizada del entorno rural como forma de definir una suerte de ser nacional (en la línea que va de sus primeros poemas, de fines de la década de 1920, a "The Great Hunger", de 1942) y la abierta distancia con instancias políticas y académicas (la censura, la Universidad).

Entre los primeros poemas encontramos un lirismo que se demora en la contemplación pastoral, contemplación no exenta de un cierto tono místico: "a beautiful landscape is contemplated by the poet labourer, a place of divine manifestation, where the privileged viewer may have a mystical vision" (Campbell 2003: 43). Son principalmente poemas breves, por ejemplo "Ploughman" que dio título a la primera colección publicada en 1936. El poema destaca el paisaje rural y sus habitantes, incluido el poeta que está presente en el pronombre "I" que inicia el primer verso de las dos primeras y última estrofas. No es ajeno a lo que describe, "Kavanagh's poetry fashioned an anthropology of rural Ireland in which the poet becomes a native participant with a gift for observation" (Alderman \& Blanton 2009: 97). Asimila la labor rural - arar - con la artística pintar - y ambas, a su vez, con una tranquilidad y éxtasis místico: el trabajo es una forma de plegaria -"Like a prayer" -. La operación se pone en evidencia en la última estrofa:

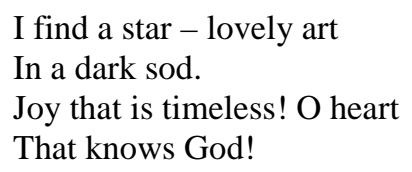

Esta operación sería patrimonio, obligación, del poeta: "Sweet May is gone, and now must poets croon / The praises of a rather stupid June" ("After May"). Una parte de la contemplación de la naturaleza - y del trabajo rural - es ser consciente del cambio de estaciones, de ahí la cantidad de alusiones a los meses del año títulos y cuerpo de varios de estos primeros poemas. Otra lectura posible es pensar esta operación desde una forma de trascendencia, un intento de establecer una unión, una continuidad entre el hombre y la naturaleza en poemas como "To a Late Poplar" o "To a Blackbird". En este último invierte el esquema de "Ploughsman", el poeta usa la segunda persona para hacerse destinatario de las palabras del ave del título que no solo lo define como poeta sino que reconoce un vínculo mutuo - "O pagan poet, you / and I are one" - que se condensa, a partir del tercer verso, en el uso de la primera persona plural "we are kindred" - o incluso en la aspiración mística final "Pleading for our conversion / with the Most High". Este vínculo con la naturaleza adquiere una dimensión personal en "Poplar Memory" donde el padre muerto ("My father dreamt forests, he is dead") prevalece, es una presencia activa ("peering"), en la contem- 
plación que el poeta hace de los bosques, análogos a los que el padre había soñado en vida. Se diferencia así del tópico de la escritura y la lectura como una suerte de extensión de la vida más allá de la muerte, rastreable por ejemplo en la lengua inglesa hasta el Soneto XVIII de Shakespeare ("So long as men can breathe, or eyes can see / So long lives this, and this gives life to thee").

Sin embargo, no todo es una recreación idílica en un paisaje de ensueño sin angustias o conflictos. En lo que hace al paisaje o la naturaleza, en "Beech tree" describe el proceso de plantación de un árbol en febrero al que protegerá de los elementos y los animales en meses posteriores. El esfuerzo resulta fútil ya que

It is August now, I have hoped,

But I hope no more -

My beech tree will never hide sparrows

From hungry hawks.

(Tal vez sea interesante notar que el "Beech tree" al que se refiere el título no es un árbol nativo de Irlanda sino una especie exótica que fue introducida y plantada extensivamente a partir el siglo XVIII y es, hasta hoy, una plaga que afecta a especies autóctonas).

En el aspecto humano, un primer acercamiento se realiza en el poema "My People" donde se utiliza el diálogo para describir y diferenciar a los campesinos de la visión que un viajero citadino - "stranger" - tiene de ellos. "Tis not so" dirá el poeta, que al igual que en "Ploughman" se incluirá entre los desdichados campesinos ("my people", "my peasant folk"), antes de enumerar sus variadas postergaciones. Tamizadas por la religión (la mayúscula en "Pride" - pecado capital - y la referencia a la espera de un mundo donde "wrongs are righted", por ejemplo), destaca la pobreza y la "condena" ¿divina? ("They work because Judge Want condemns the drones") a desempeñar un trabajo manual en oposición al trabajo intelectual ("they cannot be schoolmasters"); condena frente a la que el poeta tendría una dispensa, marcada por la alternancia entre la primera y tercera personas; la diferencia entre el "They work" o "they cannot be" en lugar del esperable "we". Una incomodidad, si se quiere, respecto a la condición de poeta entre esas gentes laboriosas con las que aparece relacionada la soledad
En "Inniskeen Road: July Evening" la tranquilidad y el silencio rural devienen soledad y vacío señalados y remarcados por la ausencia de sombras y sonidos: "no shadow thrown / That might turn out a man or woman, not / A footfall tapping secrecies of stone". Sombras y sonidos, ambos sustantivos abstractos que se oponen a las concretas bicicletas con las que otros se dirigen al baile. La imagen de la soledad del poeta se completa con la comparación con Alexander Selkirk y la idea de ser rey de "banks and stones and every blooming thing". En forma similar, el brevísimo "Anna Quinn" presenta a modo de preguntas a Dios la idea de una soledad eterna, una vida sin amor que pasa, como la mujer del título o la luz del sol sobre el pasto ("The loveliness of life before me pass / Like Anna Quinn or sunlight on the grass?") en contraste con la presencia post-mortem del padre en la contemplación de los bosques señalada previamente en "Poplar Memory". El amor es ajeno al ser poeta, su destino es la soledad - "It is tragic to be a poet now / And not a lover" ("April Dusk") -, concepto presente también en "Poet" donde se describe como un monje en una celda gris, nuevamente aislado de "The light, the laugh, the dance". Separado de sus pares campesinos, también se distancia de otros poetas (y de la visión positiva del poeta que debe cantar de "After May") en "The Irony of It":

I have not the fine audacity of men

Who have mastered the pen

Or the purse.

The complexes of many slaves are in my verse.

When I straighten my shoulders to look at the world boldly,

I see talent coldly

Damning me to stooped attrition.

Mine was a beggar's mission.

To dreams of beauty I should have been born blind.

I should have been content to walk behind,

Watching the mirror-stones

For the reflection of God's delight:

A second-hand teller of the story,

A second-hand glory.

It was not right

That my mind should have echoed life's overtones,

That I should have seen a flower

Petalled in mighty power. 
Esta distinción entre el trabajo manual y el intelectual retoma la descripción del campesinado señalada en "My People" y concluye en "The Hired Boy". En ese poema expresa un deseo de diferenciación, "Let me be no wiser than the dull / And leg-dragged boy" (subrayado propio), y la conciencia de que rechazar el "be wiser" implica resignarse a "To be damned and yet to live", como el chico campesino del título.

El ensueño pastoral convive entonces con esta visión negativa, de aislamiento, en la que ni la naturaleza ni la poesía llegan a conformar una opción de solaz. Las imágenes pastorales, el abundante verdor del pasto ("grass") deviene barro ("clay") en "The Great Hunger" pasando antes por campos oscuros ("dark fields") y tierra rocosa gris en el poema "Stony Grey Soil". Este último es una rememoración infantil en la que básicamente acusa a esa tierra rocosa de Monaghan de haberle arruinado la vida. En una visión mucho más oscura que la previamente desarrollada en "Monaghan Hills" (y la, en contraste, conciliatoria de "From Monaghan to the Grand Canal", de 1959), el verde es reemplazado por el gris; los pastos por las rocas y el barro en un hábil juego de palabras que combina "clod" con "clog". "your clod-conceived" propone, a partir de la doble significación de "clod" ("pedazo de barro" y "estúpido o "poco inteligente"), una suerte de determinismo a un destino de trabajo rural, no intelectual. De la misma manera funcionaría "You clogged the feet of my boyhood", siendo "clod" a la vez un "zueco" (un tipo de calzado asociado a tareas rurales) de barro que se forma en los pies del niño que trabaja la tierra, y un "estorbo", tanto en un sentido literal - la dificultad de caminar en el barro - como en un sentido abstracto - en alusión a las dificultades y carencias -. En relación con esto, creo que cabe recuperar un dato biográfico: Kavanagh dejó la escuela a los 13 años para trabajar en el campo y hacerse aprendiz en el taller de su padre, que era zapatero. Aunque otros poemas contemporáneos recuperan una infancia más positiva - "A Christmas Childhood", "The Long Garden" o "'Primrose" -, en "Monaghan Hills" el recuerdo infantil se detiene en la forma en que las tierras de Monaghan le quitaron su juventud y alegría, dejando marcas en su frente. Contrastan los "lonely verses" del poema presente con el "first gay flight of my lyric" del pasado y los poblados que menciona al final, queridos en su juventud pero que son ahora "places of prohibition, constriction and death. The poem is a direct address to the soil, characterised not as fructive and supportive, but as manipulative and malign" (Campbell 2003: 45).

El idilio tiene entonces un costado negativo, se confronta lo pastoral con lo anti-pastoral que Seamus Heaney caracterizó, respectivamente, como una representación de "idealised landscape with contented figures" en contraste con la representación de "sweat and pain and deprivation" (Citado en Campbell 2003: 42). Estos tres elementos, dispersos en los poemas "negativos" más arriba abordados, se condensan en el extenso "The Great Hunger" en la figura del campesino Patrick Maguire.

El poema aparece enmarcado por los ecos bíblicos del "Clay is the word and clay is the flesh" inicial y el "apocalypse of clay" final. También como marco aparecen referencias teatrales, promediando la primera estrofa el poeta propone "We will wait and watch the tragedy to the last curtain", esa "curtain" llegará en la sección final del poema: "Applause, applause, / The curtain falls. I Applause, applause" seguidos de "Silence, silence. The story is done". A pesar de estas referencias al teatro, las voces no se presentan ordenadas en diálogos (como en "My People" o "The Wake of Books") ni la expectativa que abre "wait and watch" (y que cierra "The story is done") conlleva una progresión temporal lineal. En la primera sección se suceden desordenadamente meses, estaciones $y$ festividades en una temporalidad abierta que contrasta con el perfectivo, a su vez enfatizado por la idea de la muerte -"Maguire was faithful to death"-. La temporalidad del poema se organiza a partir de una alternancia de aspecto - perfectivo, durativo - y saltos cronológicos; en la sección II se menciona que Maguire tenía sesenta y cinco años al morir su madre pero en la octava se recuerda "Sometime in July / When he was thirty-four or -five". Esta construcción de una temporalidad no-cronológica se conjuga con los ciclos de la naturaleza (y, consecuentemente, del trabajo rural) para generar un matiz de ambivalencia $o$ indeterminación - "Tomorrow is Wednesday who cares?" -. La repetición de esos ciclos sumada a la futilidad de un trabajo rural en una 
tierra infértil, barro ("clay") antes que pastura ("grass"), genera una progresión en la que no hay progreso de la misma forma en que, en el aspecto familiar o social, no hay sucesión. Enfatiza así, desde lo temporal, la representación negativa de la vida de Maguire, ese encierro del que no hay escape. Esta es la clave del poema que será sintetizada en la imagen de la cabra atada en la sección XIII: el encierro en ciclos inútiles, la falta de alternativas, la desesperanza, atraviesan el poema y condicionan las relaciones de Maguire con el campo, las mujeres y, particularmente, la madre.

La madre de Maguire aparece en la sección II; allí es presentada como "Wife and mother in one", y un par de versos después el sentido de "O he loved his mother / Above all others" es neutralizado por "O he loved his ploughs". "Above all others" destaca el lugar de la madre pero la repetición de "O he loved his" la equipara al arado. Los campesinos, a su vez, son retratados en el segundo verso de la Sección I como "mechanized scare-crows"; doblemente deshumanizados, son espantapájaros y máquinas, lo cual marca una distancia también con la idea de modernización o progreso (más adelante, en la sección IX, se afirma que "A man is what is written on the label", el campesino queda reducido a la "etiqueta", como un producto o una materia prima). En esa primera aparición de los campesinos se recupera también el contraste entre el trabajo rural y el intelectual, el verso "Is there some light of imagination in these wet clods?" opone la "imaginación" al "barro" lo que, a su vez, permite trazar una linea al "clod" y los "dark fields" del poema "Stony Grey Soil". A la vez, se observa una cierta pasividad en el trabajo en tanto el componente activo no está marcado por el verbo - "move" - sino que se recupera a partir del sustantivo "machine" y por el poeta y lectores que los observan ("If we watch them") hasta que, al final de esa primera estrofa ("Till the last soul / passively like a bag of wet clay / Rolls down the side of the hill") nuevamente aparecen deshumanizados, como bolsas de barro húmedo que ruedan "pasivamente" montaña abajo.

La misma naturaleza pierde el halo pastoral en esa estrofa introductoria - "Here crows gabble over worms and frogs / And the gulls like old newspapers are blown clear of the hedges, luckily" - lo cual no quita que, ocasionalmente en secciones posteriores, un resto místico/ pastoral echará luz sobre el lodazal: "Yet sometimes when the sun comes through a gap / These men know God the Father in a tree". Pero solo ocasionalmente, el tono general en torno a la naturaleza es de severidad e infertilidad, incluso artística, la belleza de la naturaleza no consigue sacarle palabra a una musa muda en el final de la sección VI:

He sat on the railway slope and watched the evening,

Too beautifully perfect to use,

And his three wishes were three stones too sharp to sit on,

Too hard to carve. Three frozen idols of a speechless muse

El resultado de ese silencio estaría en la sección VIII, caracterizada por la acumulación de versos repetidos - como "Sitting on a wooden gate" o "Said whatever came into his head" - que aparecen en grupos de tres. La sección está construida rítmicamente a partir de un esquema muy sencillo - que contrasta con el verso libre del resto del poema - mediante la repetición de palabras y fonemas finales: damn-sang-fat-that, head-away-spend-them etc; como el mismo poeta declara: "He didn't care a damn / Said whatever came into his head / And inconsequently sang".

A partir de la figura de Maguire se construye un retrato brutalmente honesto de la vida campesina en el que el "sweat, pain and deprivation" que mencionaba Heaney rivaliza con los mitos pastorales del Revival. La visión del campesinado de Kavanagh está lejos de la glorificación que elaboró Yeats:

\begin{abstract}
Although the literal idea of a peasant is of a farm labouring person, in fact a peasant is all that mass of humanity which lives below a certain level of consciousness. They live in the dark cave of the unconscious and they scream when they see the light (citado en Kiberd 2005: 33)
\end{abstract}

De hecho, señala Kiberd, se acerca al Stephen Hero de Joyce: "The glorified peasantry all seem to me as like one another as a peascod is to another peascod. They can spot a false coin but they represent no very admirable type of culture... They live a life of dull routine, the calculation of coppers, the weekly debauch and the weekly piety" (cit. en Kiberd 1996: 503). La madre - madre y esposa - 
es retratada negativamente, es un personaje activo que manipula y subyuga a Maguire. El verso de la sección I "And he knows that his own heart is calling his mother a liar" la describe como mentirosa - sobre lo que volverá en la sección VII - a la vez que muestra la pasividad de Maguire, que lo sabe y no hace nada al respecto. La alternancia entre "he" y "his own heart" marca una escisión asimilable a la ambigüedad antes señalada. Maguire aparece dividido, la voz de la madre en la sección XI es comparada a un cuchillo que "It cut him up the middle till he became more woman than man". Esa representación de un Maguire feminizado, castrado -idea que se extiende a otros hombres en la sección II al hablar de los campos, "Where eunuchs can be men"-, se presenta también en relación a la escritura "Nobody will ever read the wild, sprawling, scrawling $\underline{\mathrm{mad}}$ woman's signature, / The hysteria and the boredom of the enclosed nun of his thought" (sección IX, subrayado propio) y al envejecimiento "It was the menopause, the misery-pause" (sección XI). Hombre y eunuco, el hambre del título no alude tanto a la histórica hambruna del siglo XIX como al deseo sexual no consumado. Maguire, hijo y esposo a la vez, está casado con los campos y su relación con otras mujeres está marcada por la pasividad: en la sección VII se limita a observar a Agnes levantarse la falda y en la sección XI evita el contacto con chicas escolares por el miedo a la cárcel y la ley, miedo análogo al que produce la religión cuando, en la sección IV, "He met a girl carrying a basket ... And he saw Sin". Religión y madre formarán un tandem represor que se articula a partir del pecado: "Now go to Mass and pray and confess your sins / And you'll have all the luck,' his mother said". Los únicos actos de Maguire en relación al sexo son masturbarse o darse tiempo, "he gave himself another year" (sección IX), año en el que espera una nueva vida, con matrimonio $y$ dinero. La falta de consumación del deseo sexual excede a Maguire, se proyecta sobre los otros hombres del condado que pueden ver pero no mirar:

The young women ran wild

And dreamed of a child.

But no one would take them,

No man could ever see

That their skirts had loosed buttons
Deliberately loosed buttons.

$\mathrm{O}$ the men were as blind as could be (sección VIII)

y, a su vez, puede ser asimilada a la infertilidad del campo:

In that country, in that metaphysical land,

Where flesh was a thought more spiritual than music,

Among the stars - out of the reach of the peasant's hand.

(sección VII)

Esta infertilidad suma un aspecto a la idea de la temporalidad ambigua previamente mencionada, en lugar de progresión familiar se aprecia una especie de atemporal presente en el que el soltero(n) Maguire sigue unido “To a mother's womb by the wind-toughened navel-cord / Like a goat tethered to the stump of a tree / He circles around and around" (Sección XIII). Estos dos versos concentran la idiosincrasia de Maguire - y, por extensión, al campesinado -. En principio, la dependencia de la madre en la imagen del cordón umbilical que, además, junto con "womb" remite a un estado embrionario de desarrollo donde la dependencia es mucho más estrecha, una simbiosis. El verso siguiente permite reponer una relación similar con la granja y el trabajo rural. Aparece atado a un "tocón" ("stump"), un resto de árbol; esta representación difiere de los árboles en poemas previos, asociados con la vida y una visión positiva de la naturaleza y la relación que el hombre tiene con ella. Al mismo tiempo, "Stump" puede pensarse como "muñón" y, en ese sentido, también podría relacionarse con la vida truncada de Maguire o, directamente, a su castración. En el mismo verso Maguire aparece animalizado a partir de la comparación con la cabra atada. Los círculos que traza se asocian a los ciclos de la naturaleza que, a su vez, determinan los del trabajo rural conformando una temporalidad donde el progreso no necesariamente implica progresión: se avanza pero no se llega a ninguna parte, no hay salida de ese círculo, lo que llevará a Maguire a clamar al Cielo en el último verso de la Sección XII: "O Christ! I am locked in a stable with pigs and cows for ever".

El poema presenta una doble negatividad en el retrato de Maguire, no solo la vida es gris y sin sentido ("It means nothing / Not a damn thing", sección V) sino que, en esa escisión 
señalada antes, es consciente de la situación pero no hace nada, porque no puede hacer nada: "Is there nothing he can do? / Is there no escape? / No escape, no escape" (sección XIII). Tampoco encuentra solaz en elementos naturales o místicos. La naturaleza es sinónimo de trabajo, son escasas las apariciones del verde, la luz solar o el agua. Dios aparece como fundamento, causa (o excusa) de la situación: "the grief and defeat of men like these peasants / Is God's way - maybe -" (sección XI). Esta determinación religiosa aparece en la sección VIII en la idea de la vida como "purgatorio", como un "mal necesario":

\section{And Patrick Maguire \\ From his purgatory fire \\ Called the gods of the Christian to prove}

That this twisted skein

Was the necessary pain

And not the rope that was strangling true love

Al igual que Maguire, Dios aparece escindido "God is not all / In one place, complete" (sección VI) y no responde. En un poema previo, "Why Sorrow?" el padre Mat dice:

Love, happiness, riches,

Christ cannot give. He is the bitter-tasted, wrong-turned.

You will get

From Christ if you pray for love a laugh too late,

And riches Christly-come will be desire

Without escape for it

En esa línea, el consuelo que Dios ofrece(ría) es un consuelo final: "Christ will meet them at the end of the world, the slow and speedier. I But the fields say: only Time can bless" (sección IV), similar al "await the world where wrongs are righted" de "My People". El paradójico "slow and speedier" nuevamente instala esa temporalidad ambigua, circular, en la cual "only Time can bless" parece irónico. Las mayúsculas permiten asociar "Time" con "Christ" en una relación mediada por los "fields" pero el adversativo "but" marca una distancia, como si los campos - a pesar de la minúscula - fueran los que tienen la última palabra. Naturaleza e Iglesia aparecen asociadas en la presión negativa que ejercen sobre los campesinos:
Life dried in the veins of these women and men:

The grey and grief and unlove,

The bones in the backs of their hands,

And the chapel pressing its low ceiling over them.

$$
\text { (sección IX) }
$$

Habría en los poemas de Kavanagh una diferencia entre Dios o Cristo y la Iglesia o, mejor, una consciencia de la forma en que la Iglesia en tanto institución utiliza a Dios para ejercer un control represivo (la "chapel pressing its low ceiling" de los versos previos). Maguire depositaría una cierta confianza en Dios a pesar de reconocerlo como instaurador del orden que debe padecer, mientras que con la Iglesia la relación está teñida de sospecha. El padre Mat del poema "Why Sorrow?" antes mencionado vive con miedo de que alguien le escriba al Obispo contándole "escándalos" o la forma en que "worshipped more the flowers in the garden / Than God", verso en el que queda expresada la distancia entre el sacerdote y Dios. En "The Great Hunger", la Iglesia se asocia al control represivo de la madre y la naturaleza, en la sección VII la madre ordena a Maguire ir a misa y confesar sus pecados y mientras ella "was setting up the lie / She trusted in Nature that never deceives ... Religion's walls expand to the push of nature".

Este contexto condiciona el desarrollo personal y comunal. Maguire, que no puede hablar con mujeres por miedo (a la ley, a la religión, a la madre), habla solo o con los caballos: "One talks to the horse as to a brother" (sección XIV) lo que remarca la soledad, la animalización y la descomposición de la familia como unidad (lo cual ya estaba instalado a partir de la relación con la madre). Las charlas de los campesinos son completamente banales, así como las lecturas (cfr. secciones IX y X), la comunidad rural también aparece descompuesta, marcada por los celos y la rivalidad - "From every second hill a neighbour watches / With all the sharpened interest of rivalry" (sección III) -. Un ambiente completamente distinto al que el Revival y la propaganda política de la nueva república intentaron construir, la "Irlanda ideal" que Éamon de Valera describió en su famoso discurso del 17 de marzo de 1943, "The Ireland that we dreamed of": 
The ideal Ireland that we would have, the Ireland that we dreamed of, would be the home of a people who valued material wealth only as a basis for right living, of a people who, satisfied with frugal comfort, devoted their leisure to the things of the spirit - a land whose countryside would be bright with cosy homesteads, whose fields and villages would be joyous with the sounds of industry, with the romping of sturdy children, the contest of athletic youths and the laughter of happy maidens, whose firesides would be forums for the wisdom of serene old age. The home, in short, of a people living the life that God desires that men should live (De Valera \& Moynihan 1980: 466).

La distancia de Kavanagh a estos supuestos llega a su punto más alto (y corrosivo) en la sección XIII de "The Great Hunger". Enmarcada por la "mirada" del "mundo" y los "viajeros", comienza con una exposición que resume los supuestos sobre el campesino, "fuente" de la cultura y la religión, de poetas y músicos:

The peasant has no worries;

In his little lyrical fields

He ploughs and sows;

He eats fresh food,

He loves fresh women,

He is his own master;

As it was in the Beginning,

The simpleness of peasant life.

The birds that sing for him are eternal choirs,

Everywhere he walks there are flowers.

His heart is pure,

His mind is clear,

He can talk to God as Moses and Isaiah talked -

The peasant who is only one remove from the

beasts he drives.

para luego destruir dichos supuestos en un crescendo que culmina en la imagen de la cabra atada antes mencionada, que es "the weak, washy way of true tragedy". La clave de esta operación está dada por los versos que enmarcan esa primera exposición: el mundo y los viajeros que "miran" al campesino, retomando el esquema de "My People" donde el que inquiere al poeta sobre los campesinos es un "Stranger", "extranjero", "extraño".

Kavanagh opera un cambio de paradigma, cambia el mirar "desde fuera" por un mirar "desde adentro":

Kavanagh's tirades against the poetry and ideology of the Revival were spoken from the viewpoint of a farmer-poet dismayed by writers of national pastoral who, in many cases, had little genuine experience of rural, let alone agricultural life (Campbell 2003: 43).

Parte de ese cambio de paradigma es anteponer al provincialismo el parroquialismo. Pensar unidades pequeñas y cohesivas de comunidad - las parroquias - a las que considera "base" de todas las "grandes civilizaciones", el "Parochialism is universal: it deals with the fundamentals" (cfr. O'Grady 1996), por lo que no es extraño que en "Epic" asimile una disputa territorial local al tratado de 1938 sobre Checoslovaquia. Homero, ante la pregunta de qué es más importante, responde que construyó la Iliada a partir de "A local row".

En los poemas que recorrimos, "The Great Hunger" pero también otros como "My People", "The Hired Boy" o "The Irony of It", se aprecia cómo la voz de Kavanagh parece construirse a partir del contraste entre dos paradigmas: la ciudad y el campo, la educación y la experiencia, los poetas y los campesinos. Siguiendo a Seamus Heaney, el aporte de Kavanagh a la poesía Irlandesa es unir esos paradigmas:

Kavanagh's genius had achieved singlehanded what I and my grammar-schooled, arts-degreed generation were badly in need of - a poetry which linked the small farm life which produced us with the slim-volum world we were now supposed to be fit for (1988: 9).

No es, sin embargo, una intervención conciliatoria que se limita a unir. La inconformista voz lírica de Kavanagh deconstruye los paradigmas del Revival y los nacionalistas, revelando un cultura provincial construida e impuesta desde la comodidad de la ciudad. La crudeza con que ese inconformismo se manifiesta en los poemas está lejos de la pose o la afectación:

We might say that lyric celebration was to Kavanagh what witty expression was to Oscar Wilde - in the beginning, a matter of temperament, a habit of style, a disposition of the artist's fundamental nature, but, in the end, a matter of redemptive force, a resource that maintained the artist's inner freedom in the face of worldly disappointments, an infrangible dignity (Heaney 1988: 12).

Esa libertad y dignidad inquebrantable dan sustento a la voz de Kavanagh tanto en la pintura 
áspera de la vida rural de "The Great Hunger" como en el contraste satírico con el Revival de "Yeats" y están en la base de su poética inconformista:

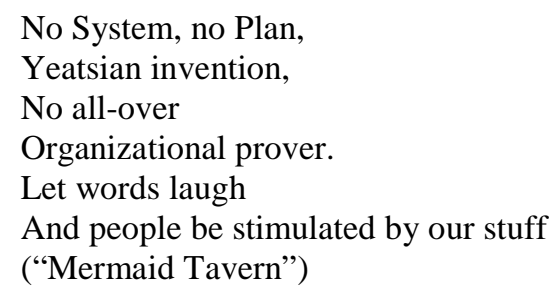

\section{Bibliografía}

Alderman, Nigel \& Blanton, C.D. 2009. A Concise Companion to Postwar British and Irish Poetry. Malden, MA: Wiley-Blackwell.

Campbell, Matthew. 2003. The Cambridge Companion to Contemporary Irish Poetry. Cambridge: Cambridge University Press.

Crotty, Patrick. 1995. Modern Irish Poetry. Belfast: Blackstaff Press.

De Valera, Éamon \& Moynihan, Maurice (ed.). 1980. "The Ireland that we dreamed of" en Speeches and Statements by Eamon De Valera: 1917-73. Dublin: Gill \& Macmillan. 466-469.

Rafroidi, Patrick. 1987. "The sense of place in Seamus Heaney's poetry”, en Genet, J. 1987. Studies on Seamus Heaney. Caen: Centre de publications de l'Université de Caen. 79-88. (disponible en: http://books.openedition.org/puc/201 [consultado: 20/10/2014]

Gillis, Alan. 2005. Irish Poetry of the 1930s. Oxford: Oxford University Press.

Heaney, Seamus. 1988. "The Placeless Heaven: Another Look at Kavanagh" en The Government of the Tongue: The 1986 T.S. Eliot Memorial Lectures, and Other Critical Writings, London: Faber, 3-14. Reeditado en Finders Keepers. New York: Farrar, Straus and Giroux, 2002: 146-157.

Kavanagh, Patrick. 1959. "From Monaghan to the Grand Canal". Studies: An Irish Quarterly Review Vol. 48 No. 189, 29-36. http://www.jstor.org/stable/30103526 [consultado: 20/10/2014] . 2003. A Poet's Country. Ed Antoinette Quinn. Dublin: Lilliput Press. 2005. Collected Poems. Ed. Antoinette Quinn. Londres: Penguin UK.

Kiberd, Declan. 1996. Inventing Ireland. Londres: Vintage. 2005. The Irish Writer and the World. Cambridge: Cambridge University Press.

O'Grady, Thomas. 1996. "The Parish and the Universe: A Comparative Study of Patrick Kavanagh and William Carleton" en Studies: An Irish Quarterly Review, Vol. 85 No. 337, 17-26. http://www.jstor.org/stable/30092026 [consultado: 20/10/2014]

Received $20^{\text {th }}$ November $2014 \quad$ Last version $21^{\text {st }}$ January 2015

Maximiliano Brina es Licenciado en Letras por la Universidad de Buenos Aires donde también cursó la Maestría en Estudios Literarios. Su tema de tesis versa sobre la producción poética española contemporánea. 